\title{
HAEMOLYTIC ANAEMIA IN A CHILD RECEIVING NITROFURANTOIN
}

BY

\author{
DAVID LEVY and ALICE PORGESS \\ From the Paediatric Department, Poriah Government Hospital, Tiberias, Israel
}

(RECEIVED FOR PUBLICATION MAY 28, 1958)

In 1956, West and Zimmerman reported a "first case' of haemolytic anaemia, apparently caused by the use of nitrofurantoin (Furadantin). Since then, no further reports of this untoward effect of the drug have appeared in the literature.

Recently a case of acute pyelonephritis treated with Furadantin, observed in the Paediatric Department of the Poriah Government Hospital in Tiberias, developed severe haemolytic anaemia when given this drug.

\section{Case Report}

S.I., a male baby of Iraqui origin, was admitted to this department at the age of 10 months. He was born normally, after a normal full-term pregnancy, the eighth child in the family. He had been breast fed all his life. No haemolytic disease was reported among the other children or the parents of the baby.

A week before admission the infant was seen by a local physician on account of watery stools and vomiting. The treatment given was, reportedly, not effective.

On admission, the baby was severely ill. He was semi-conscious; breathing was deep and rapid, giving the impression of severe metabolic acidosis. Skin turgor was practically non-existent. The liver edge was felt $3 \mathrm{~cm}$. below the costal margin. The temperature was $39^{\circ} \mathrm{C}$., and weight $7 \cdot 3 \mathrm{~kg}$.

Laboratory examinations on admission showed the following results: $\mathrm{Hb} .11 .0 \mathrm{~g}$. per $100 \mathrm{ml}$.; R.B.C. $3,900,000$ per c.mm.; W.B.C. 41,000 per c.mm. (stab 7\%, neutrophils $68 \%$, lymphocytes $18 \%$, monocytes $1 \%$, eosinophils $1 \%$, plasma cells $2 \%$ ); reticulocytes $3 \%$. Repeated urine examinations showed albumin + , white blood cells in large clumps and many granular casts. Stool examination was negative; stool culture was sterile for Shigella and Salmonella. Old tuberculin (5 TU) intracutaneously caused no local reaction 48 hours after injection.

It was apparent that this baby was suffering from dehydration and electrolyte imbalance; he was therefore given intravenously physiological solutions with added base. During the 24 hours after admission $600 \mathrm{ml}$. of standard solution, saline and glucose $5 \%$ aa, $400 \mathrm{ml}$. of $5 \%$ glucose solution and $50 \mathrm{ml}$. of $1 / 6$ molar sodium lactate were administered. The baby was also given Neomycin $400 \mathrm{mg}$. daily, in four equal doses.
On the day after admission the baby's condition was markedly improved; body weight reached $8.1 \mathrm{~kg}$; the number of stools was reduced and no clinical signs of acidosis were apparent. On the fourth day of hospitalization stools were normal in appearance and number.

On the third day of his hospital stay, because of the urinary tract infection, a course of nitrofurantoin, $50 \mathrm{mg}$., three times a day, was started. On the fourth day of this treatment he passed red dark-coloured urine. Administration of nitrofurantoin was discontinued, after a total dose of $700 \mathrm{mg}$. had been given, a total of $90 \mathrm{mg}$. per $\mathrm{kg}$. of body weight.

On this day the red blood cell count was 980,000 c.mm. with a haemoglobin level of $3 \mathrm{~g}$. per $100 \mathrm{ml}$. The reticulocyte count was $8 \%$, platelets 140,000 per c.mm.; haematocrit $17 \%$. The total serum bilirubin level was $2.82 \mathrm{mg}$. per $100 \mathrm{ml}$; urea $38.5 \mathrm{mg}$. per $100 \mathrm{ml}$. The total plasma protein was $5.8 \mathrm{~g}$. per $100 \mathrm{ml}$. (3.08 albumen and 2.72 globulin). A Coombs test, direct and indirect, was completely negative. Auto-antibodies at $36^{\circ} \mathrm{C}$. and at $6^{\circ} \mathrm{C}$. were not found. No autohaemolysins and isohaemolysins were discovered after adding complement. Bone-marrow examination showed increased erythropoiesis with an $\mathrm{M}: \mathrm{E}$ ratio of $1 \cdot 7: 1$. Paper electrophoresis of haemoglobin showed haemoglobin A only. By alkali denaturation $3 \cdot 1 \%$ foetal haemoglobin was found (normal for the patient's age). There was no bile in the urine, but haemoglobin was present.

The baby was given $450 \mathrm{ml}$. of blood over a six-hour period. Haemoglobin went up to $7 \cdot 4 \mathrm{~g}$. per $100 \mathrm{ml}$., the red blood cell count to $2,810,000$ per c.mm. A week later further regeneration brought the red blood cell count to $3,200,000$ per c.mm. and the haemoglobin rose to $9.8 \mathrm{~g}$. per $100 \mathrm{ml}$. The total serum bilirubin level fell to $1 \mathrm{mg}$. per $100 \mathrm{ml}$. with a direct fraction of $0.6 \mathrm{mg}$.

Treatment was continued with Achromycin $300 \mathrm{mg}$. per day. The baby made an unhampered recovery from the urinary tract infection and was discharged after 28 days of hospitalization.

\section{Comment}

The minor side effects of nitrofurantoin are well known and the clinical picture is generally familiar to physicians. Nausea, vomiting, skin rashes, headache, diarrhoea and dizziness have been described 
occasionally. These effects are purported to subside rapidly when the drug is withdrawn or the dosage reduced.

Rare cases of more severe toxic effects have also been reported. Thus Hasen and Moore (1954) have reported a reduced white blood cell count of 2,900 per c.mm. with a normal differential count in one of 68 patients treated with Furadantin. West and Zimmerman (1956) described the appearance in a negro male of haemolytic anaemia following the administration of nitrofurantoin. Whereas haematological and blood chemistry examinations seemed to provide good grounds for concluding that the haemolytic anaemia was related to the administration of nitrofurantoin in this patient, the authors properly reserved judgment as proof was not unequivocal and no other reports of this untoward reaction have been published.

Therefore the appearance of haemoglobinuria, reticulocytosis, a drastic fall in the circulating red blood cells and haemoglobin and a rise in serum bilirubin in a patient with pyelonephritis when treated with Furadantin caused profound interest and every effort was made to exclude other possible causes for haemolytic anaemia at our patient's age. On the other hand no trial was made to prove experimentally in vivo the haemolytic influence of nitrofurantoin because of the rapid haemolysis which necessitated an immediate transfusion of blood.
The mechanism of haemolysis due to nitrofurantoin is conjectural. The similarity of the nitrofurantoin-induced haemolysis to that induced by other drugs, such as the sulphonamides, is apparent. Szeinberg, Sheba, Hirshorn and Bodonyi (1957) have postulated that a constitutional congenital anomaly, namely glutathione deficiency of the red blood cells, is essential for the pathogenesis of this reaction. Their study indicates that this abnormality is fairly frequent among Jews originating from the Arab countries in Asia (Eastern Jews). No examination of the glutathione content of the red blood cells of this patient was made, as the deficiency appears with the ageing of the red blood cells, the young ones being normal.

\section{Summary}

A case of acute haemolytic anaemia occurred in an infant receiving nitrofurantoin (Furadantin) for acute pyelonephritis. No other cause for this haemolysis could be found. Haemolysis subsided after stopping the drug. Although no experimental proof is available, it seems reasonably proved that the haemolytic anaemia was caused by the action of Furadantin on the red blood cells.

\section{REFERENCES}

Hasen, H. B. and Moore, T. D. (1954). J. Amer. med. Ass, 155, 1470. Szeinberg, A., Sheba, C., Hirshorn, N. and Bodonyi, E. (1957). Blood, 12, 603 .

West, M. and Zimmerman, H. J. (1956). J. Amer. med. Ass., 162, 